\title{
Chemical Kinetics Computations of Fuel Decomposition to Aldehydes for NOx Reduction in Engine Exhaust Gas
}

\author{
Shigeto Yahata, Hayato Okuda, Norihiko Yoshikawa, and Nozomu Kanno
}

\begin{abstract}
Necessary aldehyde amount for enough NOx reduction performance with HC-SCR catalyst is studied by simulated gas tests, and feasible conditions of fuel thermal decomposition for enough aldehyde amount are obtained by chemical kinetics computations. Regarding the thermal decomposition computations, reaction processes of hexadecane $\left(\mathrm{C}_{16} \mathrm{H}_{34}\right)$ in hot air are parametrically computed. The effective production of aldehydes is observed in the two-stage ignition processes occurring in $600-700 \mathrm{~K}$. Between the first and second ignitions in $0.5 \% \mathrm{C}_{16} \mathrm{H}_{34}$ - air mixtures, a relatively stable conditions of high aldehydes concentration of $0.4-0.6 \%$ stay about 0.5 - 0.6 sec duration, which can be utilized for NOx reduction. Results show that a system, which produce aldehyde from diesel fuel by thermal decomposition, has good potential to achieve enough NOx reduction with HC-SCR catalyst in $3 \%$ fuel penalty considering the studied necessary aldehyde amount.
\end{abstract}

Index Terms-Chemical kinetics computation, aldehyde, hydrocarbon selective catalytic reduction, NOx.

\section{INTRODUCTION}

Diesel passenger car is very popular in Europe because of good fuel economy and powerful engine torque compared with petrol vehicle. The low $\mathrm{CO}_{2}$ emission characteristic of diesel engine system contributes to suppressing greenhouse warming, but technical improvements are required regarding NOx reduction technology. Although urea Selective Catalytic Reduction (SCR) system is developped for NOx reduction, the system needs large urea tank over 20 liters. So, it is difficult to install the system into small or medium size passenger cars, and infrastructure for urea supply is also big challenge. On the other hand, Hydrocarbon Selective Catalytic Reduction (HC-SCR) system can use diesel fuel for producing the reductant and does not need additional bulky storage of reductant. Regarding the HC-SCR catalyst, it is known that original diesel fuel is not efficient reductant, and aldehydes are effective reductant to improve NOx reduction performance [1]. In this study, necessary aldehyde amount for enough NOx reduction is studied, and aldehyde generation process by thermal decomposition of $\mathrm{C}_{16} \mathrm{H}_{34}$, which is a representative of diesel fuel, is investigated by chemical kinetics computations. For the chemical kinetics computations, CHEMKIN which is chemical elementary reaction software released from Reaction Design, USA is

Manuscript received June 25, 2015; revised August 29, 2015.

S. Yahata and H. Okuda are with DENSO CORP., Kariya, Japan (e-mail: shigeto_yahata@denso.co.jp, hayato_o_okuda@denso.co.jp).

N. Yoshikawa is with Nagoya University, Nagoya, Japan (e-mail: yoshikawa@yoshilab.nuae.nagoya-u.ac.jp).

N. Kanno was with Nagoya University, Nagoya, Japan. He is now with Meijo University, Nagoya, Japan (e-mail: kanno@ meijo-u.ac.jp). used. Here, Effects of heating temperature, heating time, $\mathrm{C}_{16} \mathrm{H}_{34}$ concentration, air excess ratio, and $\mathrm{O}_{2}$ concentration on the thermal decomposition are parametrically studied.

Regarding the computation analysis for the fuel thermal decomposition, conditions for hydrogen generation are studied by some researchers [2], [3]. But, studies for aldehyde generation cannot be found.

\section{II. $\mathrm{NO}_{\mathrm{x}}$ REDUCTION WITH ALDEHYDE}

At first, NOx reduction performance of HC-SCR catalyst is tested with simulated gas to evaluate necessary aldehyde amount for a sufficient NOx reduction rate. Test configuration is shown in Fig. 1. Typical HC-SCR catalyst $\mathrm{Ag} / \mathrm{Al}_{2} \mathrm{O}_{3}$ is coated on ceramic honeycomb and set in an electric furnace. The honeycomb has $20 \mathrm{~mm}$ diameter, $30 \mathrm{~mm}$ length, 400 cells per square inch, and $0.1 \mathrm{~mm}$ cell wall thickness. Simulated gas consists of $\mathrm{NO}, \mathrm{C}_{3} \mathrm{H}_{8}$, acetaldehyde $\left(\mathrm{CH}_{3} \mathrm{CHO}\right), \mathrm{O}_{2}, \mathrm{CO}_{2}, \mathrm{~N}_{2}$ and $\mathrm{H}_{2} \mathrm{O}$, and volume flow rate is set at 50,000 1/h. Catalyst outlet gas is analyzed with HORIBA MEXA-4000FT. Catalyst bed temperature is measured with K-type thermocouple.

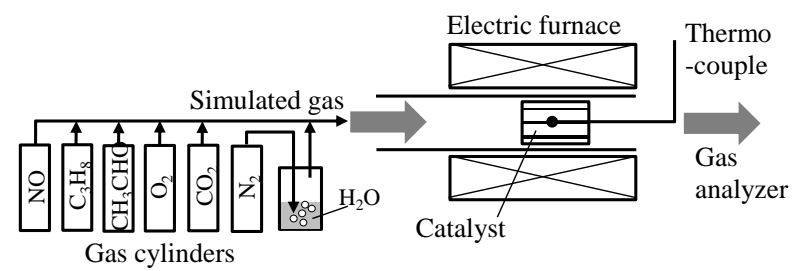

Fig. 1. NOx reduction test configuration.

Test gas condition is shown in Table I. NO is $0.02 \%, \mathrm{O}_{2}$ is $10 \%, \mathrm{CO}_{2}$ is $9 \%$ and $\mathrm{H}_{2} \mathrm{O}$ is $2 \%$ as simulated diesel exhaust gas and total reductant amount $\mathrm{C}_{3} \mathrm{H}_{8}+\mathrm{CH}_{3} \mathrm{CHO}$ is adjusted to $0.2 \%(\mathrm{C} 1)$ mole fraction. $\mathrm{CH}_{3} \mathrm{CHO}$ mole fraction is varied between $0 \%$ and $0.03 \%$ to study the effects of aldehyde amount.

TABLE I: GAS CONDITION FOR NO $\mathrm{NO}_{\mathrm{x}}$ REDUCTION TEST

\begin{tabular}{ccccc}
\hline \hline Species & \multicolumn{4}{c}{ Mole fraction [\%] } \\
\hline $\mathrm{NO}$ & \multicolumn{4}{c}{0.02} \\
$\mathrm{C}_{3} \mathrm{H}_{8}$ & 0.067 & 0.06 & 0.053 & 0.047 \\
$\mathrm{CH}_{3} \mathrm{CHO}$ & 0 & 0.01 & 0.02 & 0.03 \\
$\mathrm{O}_{2}$ & & \multicolumn{2}{c}{10} & \\
$\mathrm{CO}_{2}$ & \multicolumn{3}{c}{9} \\
$\mathrm{H}_{2} \mathrm{O}$ & \multicolumn{2}{c}{2} \\
\hline \hline
\end{tabular}

NOx reduction test results are shown in Fig. 2. Catalyst bed temperature conditions are $300 \mathrm{degC}$ and $400 \mathrm{degC}$. At 300degC NOx reduction cannot be obtained without aldehyde, and the performance is improved by the increase of aldehyde amount. It is shown that about $0.02-0.03 \%$ mole 
fraction of aldehyde is necessary to achieve target NOx conversion rate $80 \%$ in the condition. At $400 \mathrm{degC}, 50 \%$ of NOx reduction rate is obtained without aldehyde. Enough NOx conversion performance is achieved in $0.02 \%$ mole fraction of aldehyde.

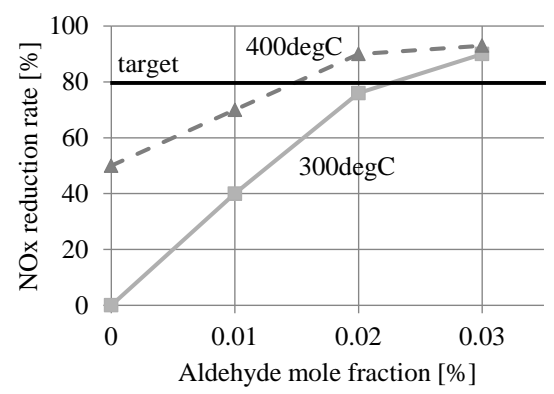

Fig. 2. NOx reduction rate agaisnt aldehyde mole fraction with $\mathrm{Ag} / \mathrm{Al}_{2} \mathrm{O}_{3}$ catalyst (total reductant $=2000 \mathrm{ppmC}, \mathrm{C}_{3} \mathrm{H}_{8}+\mathrm{CH}_{3} \mathrm{CHO}$ ).

According to the above test results, about $0.02-0.03 \%$ mole fraction of aldehyde in the exhaust gas is necessary for enough NOx conversion rate, and aldehyde is more impotant in low temperature condition. The gas temperature 300degC is too low to oxidize $\mathrm{C}_{3} \mathrm{H}_{8}$ into aldehyde on $\mathrm{Ag} / \mathrm{Al}_{2} \mathrm{O}_{3}$ catalyst.

\section{CHEMiCAl Kinetics MODEL FOR THERMAL DECOMPOSITION COMPUTATION}

Fig. 3 is envisioned NOx reduction system with aldehyde production by fuel thermal decomposition and HC-SCR catalyst. In this system, fuel and air or part of exhaust gas are fed into a component for the thermal decomposition with thermal energy, and produced aldehyde is fed into exhaust gas as the reductant.

In the following, condition to produce aldehyde by thermal decomposition of $\mathrm{C}_{16} \mathrm{H}_{34}$, which is a representative of diesel fuel, is investigated by chemical kinetics computations.

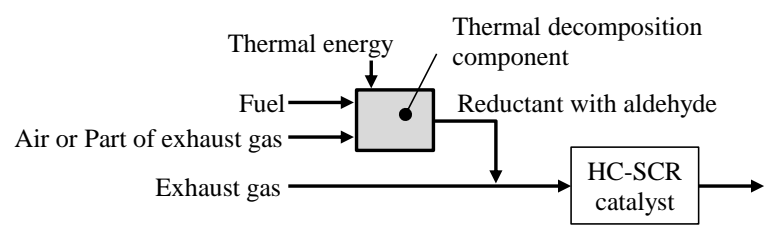

Fig. 3. NOx reduction system with aldehyede production.

In thermal decomposition analyses of $\mathrm{C}_{16} \mathrm{H}_{34}$ with CHEMKIN, normal alkane hydrocarbons combustion model proposed by Lawrence Livemore National Laboratory [4] is used, and "closed homogeneous batch reactor" in CHEMKIN is used as a reaction condition. In the chemical kinetics model, 2,116 chemical species and 8,172 elementary reaction steps are considered. Major elementary reaction steps are shown in Table II. At first proton is abstracted from $\mathrm{C}_{16} \mathrm{H}_{34}$ by $\mathrm{O}_{2}$ or $\mathrm{HO}_{2}$, after that some active species like $\mathrm{O}, \mathrm{H}, \mathrm{OH}$ and $\mathrm{CH}_{3}$ react with intermediate products yielded by decomposition of $\mathrm{C}_{16} \mathrm{H}_{34}$. The reaction 9 and 10 in Table II show the process of acetaldehyde $\left(\mathrm{CH}_{3} \mathrm{CHO}\right)$ formation. Other aldehydes including $\mathrm{HCHO}, \mathrm{C}_{2} \mathrm{H}_{5} \mathrm{CHO}$, and $\mathrm{C}_{13} \mathrm{H}_{27} \mathrm{CHO}$ are similarly generated in a massive chain reaction system. These reaction paths from alkane to aldehyde including proton abstraction and $\mathrm{O}_{2}$ addition are typical thermal decomposition reaction in low temperature condition [5], [6].

TABLE II: MAJOR ELEMENTARY REACTION STEPS IN THE REACTION MODEL

\begin{tabular}{cl}
\multicolumn{1}{c}{ Elementary reaction } \\
\hline \hline 1 & $\mathrm{nC}_{16} \mathrm{H}_{34}+\mathrm{O}_{2}=\mathrm{C}_{16} \mathrm{H}_{33}-2+\mathrm{HO}_{2}$ \\
2 & $\mathrm{nC}_{16} \mathrm{H}_{34}+\mathrm{HO}_{2}=\mathrm{C}_{16} \mathrm{H}_{33}-2+\mathrm{H}_{2} \mathrm{O}_{2}$ \\
3 & $\mathrm{C}_{16} \mathrm{H}_{33}-2+\mathrm{O}_{2}=\mathrm{C}_{16} \mathrm{H}_{33} \mathrm{O}_{2}-2$ \\
4 & $\mathrm{C}_{16} \mathrm{H}_{33} \mathrm{O}_{2}-2=\mathrm{C}_{16} \mathrm{H}_{32}-2+\mathrm{HO}_{2}$ \\
5 & $\mathrm{C}_{16} \mathrm{H}_{32}-2+\mathrm{O}=\mathrm{C}_{16} \mathrm{H}_{31}+\mathrm{OH}$ \\
6 & $\mathrm{C}_{16} \mathrm{H}_{32}-2+\mathrm{H}=\mathrm{C}_{16} \mathrm{H}_{31}+\mathrm{H}_{2}$ \\
7 & $\mathrm{C}_{16} \mathrm{H}_{32}-2+\mathrm{OH}=\mathrm{C}_{16} \mathrm{H}_{31}+\mathrm{H}_{2} \mathrm{O}$ \\
8 & $\mathrm{C}_{16} \mathrm{H}_{32}-2+\mathrm{CH}=\mathrm{C}_{16} \mathrm{H}_{31}+\mathrm{CH}_{4}$ \\
9 & $\mathrm{C}_{16} \mathrm{H}_{31}=\mathrm{C}_{12} \mathrm{H}_{23}+\mathrm{C}_{4} \mathrm{H}_{8}-1$ \\
10 & $\mathrm{C}_{4} \mathrm{H}_{8}-1+\mathrm{O}=\mathrm{CH}_{3} \mathrm{CHO}_{+} \mathrm{C}_{2} \mathrm{H}_{4}$ \\
\hline \hline
\end{tabular}

\section{COMPUTATION RESUlts}

\section{A. Influence of Initial Temperature}

At first, influence of initial temperature is investigated. Computation conditions are shown in Table III. The initial gas mixture composition is fixed as $20 \% \mathrm{O}_{2}, 2 \% \mathrm{H}_{2} \mathrm{O}, 0.5 \%$ $\mathrm{C}_{16} \mathrm{H}_{34}$, and the temperature varies $500,600,700$, and $873 \mathrm{~K}$. The mixture condition is obtained assuming that diesel fuel is injected into heated humid air, and excess air ratio which is the ratio of air amount to the stoichiometric air amount, is 1.63 .

TABLE III: COMPUTATION CONDITIONS FOR DIFFERENT INITIAL TEMPERATURES

\begin{tabular}{|c|c|c|c|c|c|c|}
\hline & & \multicolumn{5}{|c|}{ Initial condition } \\
\hline & & unit & A & B & $\mathrm{C}$ & $\mathrm{D}$ \\
\hline \multirow{4}{*}{$\begin{array}{c}\text { Mole } \\
\text { fraction }\end{array}$} & $\mathrm{O}_{2}$ & \multirow{4}{*}[\%]{} & \multicolumn{4}{|c|}{19.5} \\
\hline & $\mathrm{N}_{2}$ & & \multicolumn{4}{|c|}{78.0} \\
\hline & $\mathrm{H}_{2} \mathrm{O}$ & & \multicolumn{4}{|c|}{2.0} \\
\hline & $\mathrm{C}_{16} \mathrm{H}_{34}$ & & \multicolumn{4}{|c|}{0.5} \\
\hline \multicolumn{2}{|c|}{ Excess air ratio } & {$[-]$} & \multicolumn{4}{|c|}{1.63} \\
\hline \multicolumn{2}{|c|}{ Temperature } & {$[\mathrm{K}]$} & 500 & 600 & 700 & 873 \\
\hline
\end{tabular}

The results are shown in Fig. 4. Fig. 4a, 4b, and 4c show time variations of temperature, aldehydes mole fractions and $\mathrm{CO}_{2}$ mole fractions, respectively. At $500 \mathrm{~K}$, gas temperature is too low to induce $\mathrm{C}_{16} \mathrm{H}_{34}$ decomposition. At $600 \mathrm{~K}$, the first ignition occurs at $0.3 \mathrm{sec}$ and about $0.6 \%$ aldehydes are generated, and $0.5 \mathrm{sec}$ later the second strong exothermic ignition occurs. This is a typical two-stage ignition phenomenon. At $700 \mathrm{~K}$, a similar first ignition occurs at $0.01 \mathrm{sec}$ and about $0.4 \%$ aldehydes are generated. Under these temperature conditions, produced aldehydes stay relatively stable about $0.4-0.5 \mathrm{sec}$ before the second strong ignitions. Regarding the aldehydes generation in $700 \mathrm{~K}$ condition, radical species concentrations are also computed, and mole fractions of $\mathrm{HO}_{2}$ and $\mathrm{H}_{2} \mathrm{O}_{2}$ are shown in Fig. 5. These species are generated in the process shown in Table I. Aldehydes concentration in Fig. $1 \mathrm{~b}$ is the sum of all the generated aldehyde species and the detailed aldehyde species in $700 \mathrm{~K}$ mixture at $0.4 \mathrm{sec}$ are shown in Fig. 6. Acetaldehyde $\left(\mathrm{CH}_{3} \mathrm{CHO}\right)$ is known as an efficient reductant for HC-SCR, and other aldehydes are also effective reductants. At $873 \mathrm{~K}$, the ignition occurs only once at about $0.45 \mathrm{sec}$, and does not 
provide stable regime of aldehydes. At $873 \mathrm{~K}$ thermal dissociation of $\mathrm{C}-\mathrm{C}$ bonding occurs primarily in comparison with the weaker reaction process of aldehydes generation.

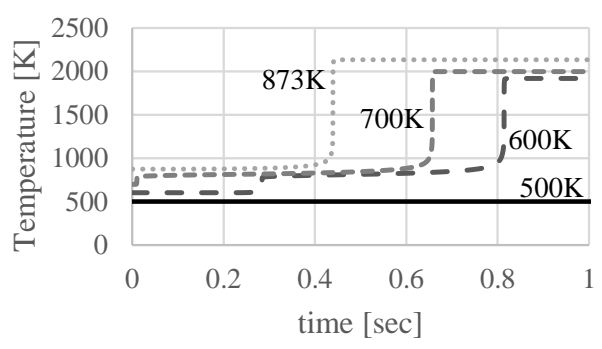

a) Temperature variations of $\mathrm{C}_{16} \mathrm{H}_{34}$ decomposition reactions for each initial temperature.

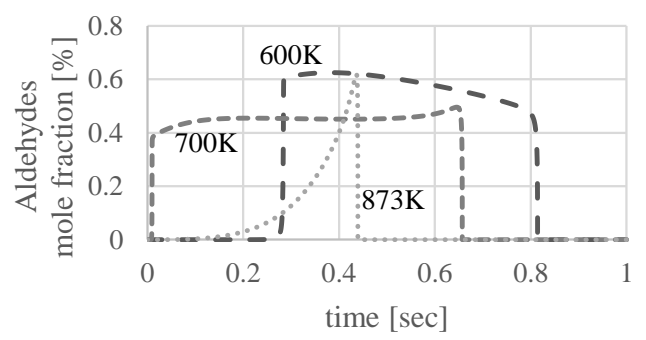

b) Aldehydes concentration variations of $\mathrm{C}_{16} \mathrm{H}_{34}$ decomposition for each initial temperature.

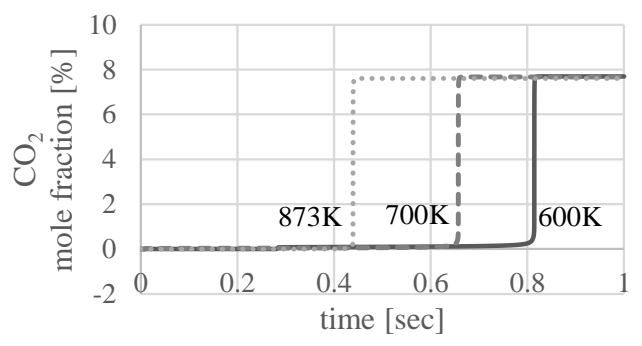

c) $\mathrm{CO}_{2}$ concentration variations of $\mathrm{C}_{16} \mathrm{H}_{34}$ decomposition reactions for each initial temperature.

Fig. 4. Temporal variations of $\mathrm{C}_{16} \mathrm{H}_{34}$ decomposition reactions in hot air

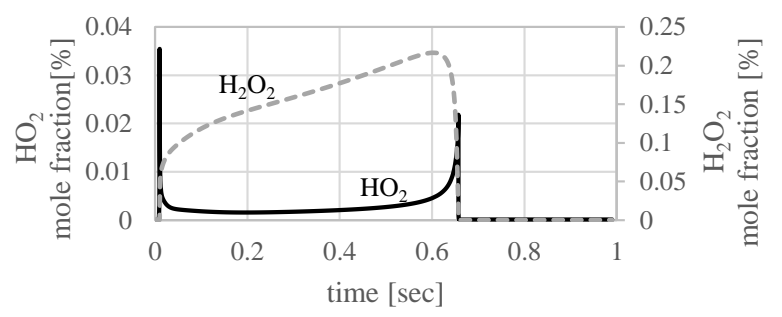

Fig. 5. $\mathrm{HO}_{2}$ and $\mathrm{H}_{2} \mathrm{O}_{2}$ concentration variations in $\mathrm{C}_{16} \mathrm{H}_{34}$ decomposition in $700 \mathrm{~K}$ air.

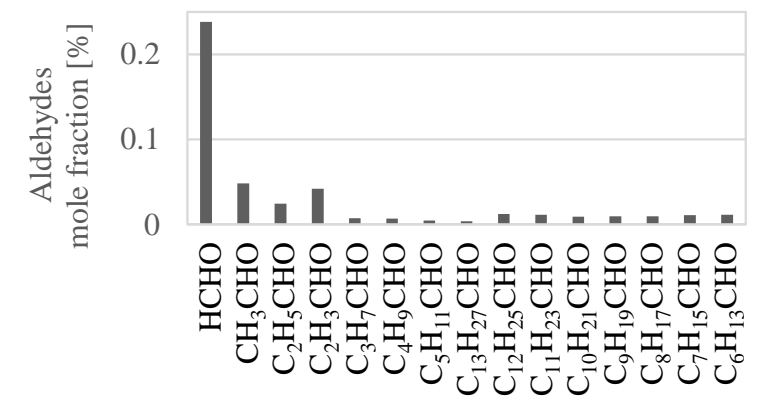

Fig. 6. Aldehyde species concentrations in $\mathrm{C}_{16} \mathrm{H}_{34}$ decomposition in $700 \mathrm{~K}$ air.

\section{B. Influence of Initial $\mathrm{C}_{16} \mathrm{H}_{34}$ Concentration}

Effects of $\mathrm{C}_{16} \mathrm{H}_{34}$ concentration on aldehydes generation are further investigated. In the fuel decomposition system, fuel injection amount should be controlled according to NOx amount in exhaust gas. Computation conditions are shown in Table IV, in which the initial mole fractions of $\mathrm{O}_{2}, \mathrm{H}_{2} \mathrm{O}$, and $\mathrm{C}_{16} \mathrm{H}_{34}$ are given. The conditions are obtained assuming that diesel fuel is injected into heated air with humidity, and excess air ratio, which is the ratio of air amount ratio to the stoichiometric air amount, is varied from 0.32 to 4.35 . In conditions $\mathrm{F}$ and $\mathrm{G}$, excess air ratio is less than 1, i.e. $\mathrm{O}_{2}$ amount is lower than necessary amount for $\mathrm{C}_{16} \mathrm{H}_{34}$ stoichiometric combustion.

TABLE IV: COMPUTATION CONDITIONS FOR DIFFERENT $\mathrm{C}_{16} \mathrm{H}_{34}$ CONCENTRATIONS

\begin{tabular}{|c|c|c|c|c|c|c|}
\hline & & \multirow{2}{*}{ unit } & \multicolumn{4}{|c|}{ Initial condition } \\
\hline & & & $\mathrm{E}$ & $\mathrm{C}$ & $\mathrm{F}$ & G \\
\hline \multirow{4}{*}{$\begin{array}{c}\text { Mole } \\
\text { fraction }\end{array}$} & $\mathrm{O}_{2}$ & \multirow{4}{*}[\%]{} & 19.6 & 19.5 & 19.4 & 19.1 \\
\hline & $\mathrm{N}_{2}$ & & 78.3 & 78.0 & 77.4 & 76.4 \\
\hline & $\mathrm{H}_{2} \mathrm{O}$ & & 2.0 & 2.0 & 2.0 & 2.0 \\
\hline & $\mathrm{C}_{16} \mathrm{H}_{34}$ & & 0.19 & 0.5 & 1.3 & 2.5 \\
\hline \multicolumn{2}{|c|}{ Excess air ratio } & {$[-]$} & 4.35 & 1.63 & 0.65 & 0.32 \\
\hline \multicolumn{2}{|c|}{ Temperature } & {$[\mathrm{K}]$} & \multicolumn{4}{|c|}{700} \\
\hline
\end{tabular}

The results in Fig. 7a, 7b, and 7c show the variations of temperature, and mole fractions of aldehydes and $\mathrm{H}_{2}$, respectively. In each condition, the two-stage ignition phenomena are observed. The aldehydes concentrations are approximately same level of initial $\mathrm{C}_{16} \mathrm{H}_{34}$ concentrations. The results show that fuel rich conditions of $F$ and $G$ can generate aldehydes. The duration of aldehydes concentration is very short in these conditions, and the control of these unstable mixtures may be difficult. Hydrogen is generated in conditions $\mathrm{F}$ and $\mathrm{G}$, as shown in Fig. $7 \mathrm{c}$, and $\mathrm{H}_{2}$ is very useful to activate silver catalyst [7], [8], which is a typical HC-SCR catalyst especially in low temperature conditions. The effective combination of aldehydes and $\mathrm{H}_{2}$ in fuel rich conditions may have a potential of providing high efficiency of $\mathrm{NO}_{\mathrm{x}}$ reduction.

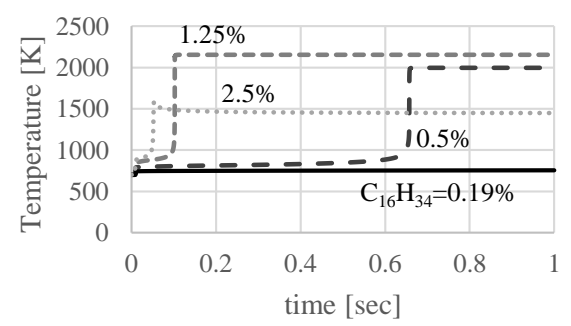

a) Temperature variations of $\mathrm{C}_{16} \mathrm{H}_{34}$ decomposition reactions for different $\mathrm{C}_{16} \mathrm{H}_{34}$ concentrations.

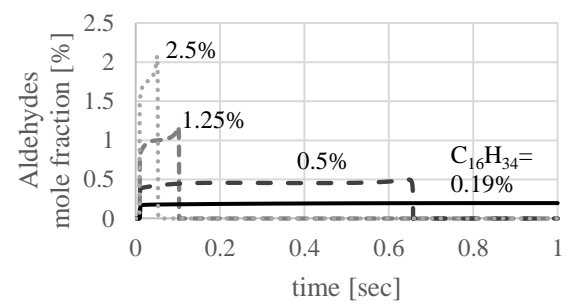

b) Aldehydes concentration variations of $\mathrm{C}_{16} \mathrm{H}_{34}$ decomposition for different $\mathrm{C}_{16} \mathrm{H}_{34}$ concentrations. 


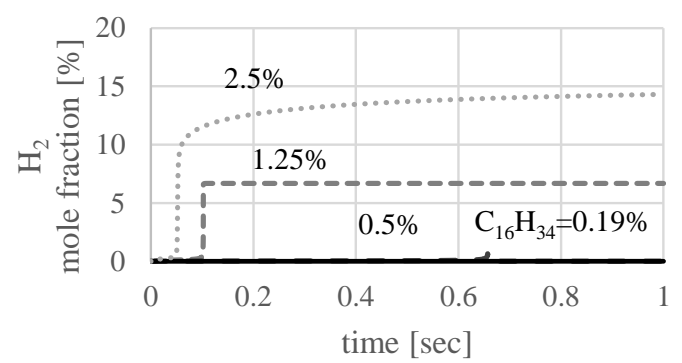

c) $\mathrm{H}_{2}$ concentration variations of $\mathrm{C}_{16} \mathrm{H}_{34}$ decomposition reactions for different $\mathrm{C}_{16} \mathrm{H}_{34}$ concentrations

Fig. 7. Temporal variations of $\mathrm{C}_{16} \mathrm{H}_{34}$ decomposition reactions in hot air containing different $\mathrm{C}_{16} \mathrm{H}_{34}$ concentrations

\section{Influence of Initial $\mathrm{O}_{2}$ Concentration}

The results so far are obtained under the heated air conditions. For the actual engine systems, computations of fuel injection into exhaust gas are necessary. Initial exhaust gas compositions are determined assuming diesel exhaust gas Computation conditions are shown in Table V. Initial $\mathrm{O}_{2}$ concentrations are $5 \%$ and $10 \%$, and $\mathrm{H}_{2} \mathrm{O}$ and $\mathrm{CO}_{2}$ concentrations are calculated considering diesel fuel combustion for each $\mathrm{O}_{2}$ concentration, temperature is $700 \mathrm{~K}$, and $\mathrm{C}_{16} \mathrm{H}_{34}$ concentration is $0.5 \%$.

TABLE V: COMPUTATION CONDITIONS FOR DIFFERENT $\mathrm{O}_{2}$ CONCENTRATIONS

\begin{tabular}{cccccc}
\hline \hline & & & \multicolumn{3}{c}{ Initial condition } \\
& & unit & $\mathrm{C}$ & $\mathrm{H}$ & $\mathrm{I}$ \\
\hline \multirow{4}{*}{ Mole } & $\mathrm{O}_{2}$ & & 19.5 & 10.0 & 5.0 \\
fraction & $\mathrm{N}_{2}$ & & 78.0 & 76.8 & 75.2 \\
& $\mathrm{CO}_{2}$ & {$[\%]$} & 0.0 & 6.4 & 9.7 \\
& $\mathrm{H}_{2} \mathrm{O}$ & & 2.0 & 6.4 & 9.7 \\
& $\mathrm{C}_{16} \mathrm{H}_{34}$ & & 0.5 & 0.5 & 0.5 \\
\multicolumn{2}{c}{ Excess air ratio } & {$[-]$} & 1.63 & 0.83 & 0.41 \\
\multicolumn{2}{c}{ Temperature } & {$[\mathrm{K}]$} & & 700 & \\
\hline \hline
\end{tabular}

The results in Fig. 8a and $8 b$ show the variations of temperature, and mole fractions of aldehydes respectively. In each condition, the first ignition occurs at almost same delay times, and the second ignition delay time becomes larger in lower $\mathrm{O}_{2}$ concentration conditions. Although excess air ratios of conditions $\mathrm{H}$ and $\mathrm{I}$ are less than 1, relatively stable aldehydes concentration is maintained, so these are better than conditions $\mathrm{F}$ and $\mathrm{G}$. Regarding aldehydes concentration, it is reduced due to $\mathrm{O}_{2}$ concentration decrease, so fuel injection amount as reductant should be controlled according to $\mathrm{O}_{2}$ concentration for effective NOx reduction strategy.

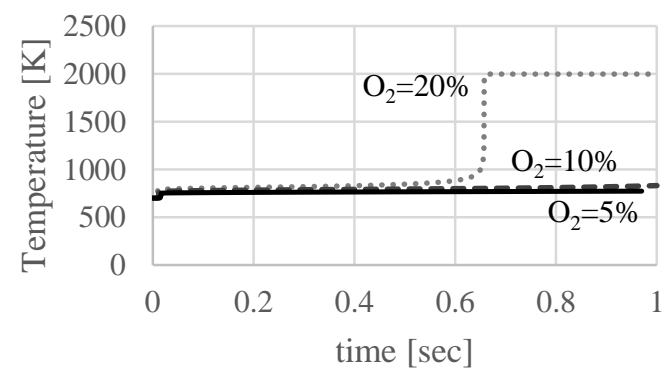

a) Temperature variations of $\mathrm{C}_{16} \mathrm{H}_{34}$ decomposition reactions for different initial $\mathrm{O}_{2}$ concentrations.

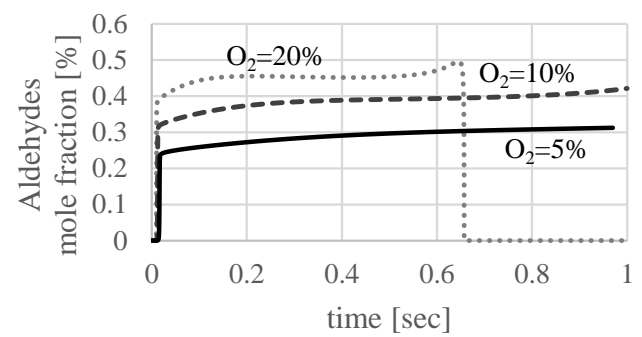

b) Aldehydes concentration variations of $\mathrm{C}_{16} \mathrm{H}_{34}$ decomposition for different initial $\mathrm{O}_{2}$ concentrations.

Fig. 8. Temporal variations of $\mathrm{C}_{16} \mathrm{H}_{34}$ decomposition reactions in hot air containing different initial $\mathrm{O}_{2}$ concentrations.

\section{Estimate of System Potential}

In the 2 nd section, it is shown that about $0.02-0.03 \%$ mole fraction of aldehyde is necessary in the exhaust gas for enough NOx reduction. In the 4th section, potentially about $0.4-0.6 \%$ mole fraction of aldehyde can be produced from $0.5 \% \mathrm{C}_{16} \mathrm{H}_{34}$ in the thermal decomposition component. From these results, system potential can be estimated as follows. For example, if flow rate in the component is $1 / 25$ against exhaust gas flow rate, $0.5 \%$ of $\mathrm{C}_{16} \mathrm{H}_{34}$ in the component corresponds to $0.32 \%(\mathrm{C} 1)$ hydrocarbon in exhaust gas, and $0.5 \%$ of aldehyde corresponds to $0.02 \%$ in exhaust gas as well. Here, the amount of aldehyde is enough for the NOx reduction, and the $\mathrm{C}_{16} \mathrm{H}_{34}$ amount corresponds to about $3 \%$ fuel penalty for diesel engine system. Enough NOx reduction rate can be achieved with $3 \%$ fuel penalty. Although effects of difference of aldehyde species or hydrocarbon species should be examined carefully, the present fuel penalty value is quite competitive against urea SCR system.

\section{CONCLUSION}

Effects of aldehyde amount on NOx reduction performance of $\mathrm{HC}-\mathrm{SCR}\left(\mathrm{Ag} / \mathrm{Al}_{2} \mathrm{O}_{3}\right)$ catalyst is studied with simulated gas. It is shown that about $0.02-0.03 \%$ mole fraction of aldehyde is necessary for enough NOx reduction.

The results of chemical kinetics computations of hexadecane $\left(\mathrm{C}_{16} \mathrm{H}_{34}\right)$ thermal decomposition are presented to evaluate the chemical kinetics processes of the fuel decomposition to aldehydes.

In case diesel fuel is injected in heated air for fuel decomposition, the most effective temperature condition is $600-700 \mathrm{~K}$. The reaction process is a two-stage ignition phenomenon. Potential aldehydes species from $\mathrm{C}_{16} \mathrm{H}_{34}$ are wide-ranging, i.e. $\mathrm{HCHO}-\mathrm{C}_{13} \mathrm{H}_{27} \mathrm{CHO}$, and aldehydes concentration is $0.4-0.6 \%$ from $0.5 \% \mathrm{C}_{16} \mathrm{H}_{34}$.

If the fuel concentration in the heated air is increased, the ratio of aldehydes concentration to fuel concentration is constant. The controllability of the system concentration may be difficult in fuel rich conditions, because the stable duration of aldehydes becomes shorter.

In case diesel fuel is injected in heated diesel exhaust gas, aldehydes concentration is reduced due to $\mathrm{O}_{2}$ concentration decrease. Fuel injection concentration should be adjusted corresponding to $\mathrm{O}_{2}$ concentrations.

System potential is estimated that enough NOx reduction rate is achieved with $3 \%$ of fuel penalty. 


\section{REFERENCES}

[1] J. H. Lee, S. J. Schmieg, and S. H. Oh, "Improved NOx reaction over the staged $\mathrm{Ag} / \mathrm{Al}_{2} \mathrm{O}_{3}$ catalyst system," Applied Catalysts A: General, vol. 342, pp. 78-86, 2008.

[2] C. Zhang and $\mathrm{H}$. Wu, "The simulation based CHEMKIN for homogeneous charge compression ignition combustion with on-board fuel reformation in the chamber," International Journal of Hydrogen Energy, vol. 37, pp. 4467-4475, 2012.

[3] Z. Al-Hamamre, "Thermodynamic and kinetic analysis of the thermal partial oxidation of $\mathrm{n}$-heptane for the production of hydrogen rich gas mixtures," International Journal of Hydrogen Energy, vol. 38, pp 11458-11469, 2013.

[4] C. K. Westbrook, W. J. Pitz, O. Herbinet, H. J. Curran, and E. J. Silke, "A detailed chemical kinetic reaction mechanism for n-Alkane hydrocarbons from n-octane to n-hexadecane," Combust. Flame, vol. 156, no. 1, pp. 181-199, 2009.

[5] K. Narayanaswamy, P. pepiot, and H. Pitsch, "A chemical mechanism for low to high temperature oxidation of n-dodecane as a component of transportation fuel surrogates," Combustion and Flame, vol. 161, pp 866-884, 2014

[6] S. M. Sarathy, C. K. Westbrook, and M. Mehl et al., "Comprehensive chemical kinetic modeling of the oxidation of 2-methylalkanes from C7 to C20," Combustion and Flame, vol. 158, pp. 2338-2357, 2011.

[7] S. Satokawa, J. Shibata, K. Shimizu, A. Satsuma, and T. Hattori, "Promotion effect of $\mathrm{H}_{2}$ on the low temperature activity of the selective reduction of $\mathrm{NO}$ by light hydrocarbons over $\mathrm{Ag} / \mathrm{Al}_{2} \mathrm{O}_{3}, "$ Applied Catalysis B: Emvironmental, vol. 42, pp179-186, 2003.

[8] P. Sazama, L. Capek, H. Drobna, Z. Sobalik, J. Dedecek, K. Arve, and B. Wichterlova, "Enhancement of decane-SCR-NOx over Ag/alumina by hydrogen, reaction kinetics and in situ FTIR and UV-vis study," Journal of Catalysis, vol. 232, pp. 302-317, 2005.

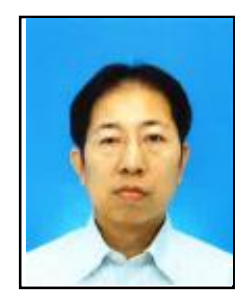

Shigeto Yahata obtained his master's degree in mechanical engineering at Nagoya University, Japan in 1998. During his graduate studies, he pursued image processing methodologies for robot vision. In 1998, he started working for Denso Corporation in Japan, and since then he has been studying after treatment systems to purify harmful exhaust gas from gasoline and diesel engines, for example diesel particulate filter system and lean $\mathrm{NO}_{\mathrm{x}}$ trap system.

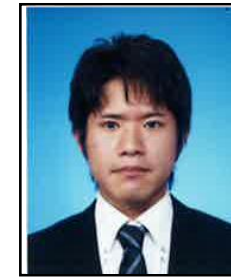

Hayato Okuda obtained his master's degree in mechanical engineering at Nagoya University, Japan in 2014. During his graduate studies, he pursued chemical kinetics related to diesel fuel reforming system for NOx after treatment. In 2014, He started working for Denso Corporation in Japan. His current job is to develop after treatment system for diesel engine system.

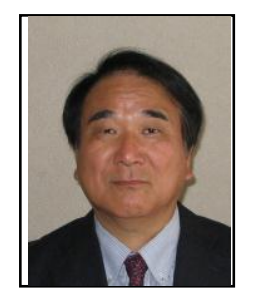

Norihiko Yoshikawa obtained his BE in aeronautics at Nagoya University in 1974, and his $\mathrm{PhD}$ at McGill University, Montreal, Canada, in 1980. During his graduate studies, he pursued the mechanism of photochemical initiation of gaseous detonation waves, and gaseous explosion is continuously one of his research interests. In 1980 he started working for Toyohashi University of Technology, and promoted to Associate Professor in 1986. He was appointed as Associate Professor at Nagoya University in 1995, and promoted to Professor in 2000. Professor Yoshikawa's current research interests are development of a damage reduction system against hydrogen explosions in nuclear power plants, laser-induced breakdown spectroscopy of solids and liquids, and laser-induced fluorescence measurement of nitrogen monoxide in combustion gases, and reduction of diesel engine exhaust.

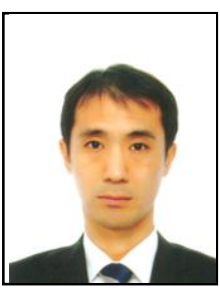

Nozomu Kanno obtained his $\mathrm{PhD}$ at University of Tokyo in 2005. During his graduate studies, he pursued chemical kinetics related to atmospheric chemistry and combustion sciences. In 2005 he started working as postdoctoral research fellow at University of Tokyo. He was appointed as Assistant Professor at Nagoya University in 2008 and Associate Professor at Meijo University in 2015. His current research interests are chemical kinetics and detailed chemical kinetics modeling for the internal combustion engine fuels and the spacecraft propellants. 
